\title{
Új, cinkona alapú organokatalizátorok elóállítása, alkalmazása és visszaforgatása
}

\author{
NAGY Sándor*, KISSZÉKELYI Péter, DARGÓ Gyula, HUSZTHY Péter és KUPAI József* \\ Budapesti Müszaki és Gazdaságtudományi Egyetem, Vegyészmérnöki és Biomérnöki Kar, \\ Szerves Kémia és Technológia Tanszék, Szent Gellért tér 4., 1111 Budapest, Magyarország
}

\section{Bevezetés}

Napjainkban kiemelten fontos szerepe van az enantiomertiszta gyógyszerhatóanyagok előállításának, ugyanis két enantiomernek akár teljesen eltérö lehet a hatása. Az enantiomerek elválasztása anyag-, energia- és költségigényes. A probléma megoldásának érdekében a kutatás és fejlesztés törekvései az enantioszelektív szintézisek felé irányulnak. A hagyományos katalizátorok mellett előtérbe került az aszimmetrikus organokatalizátorok alkalmazása.

Az organokatalizátor olyan, az aktív centrumban fématomot nem tartalmazó kisméretű szerves molekula, mely kémiai átalakulásokban katalizátorként szolgál. Ily módon nem tekintjük organokatalitikus reakciónak azokat a folyamatokat, ahol a királis szerves vegyülethez kapcsolódó Lewis-savas fématom is részt vesz a szubsztrátok aktiválásában és az átmeneti állapot stabilizálásában. ${ }^{1}$ Átmenetifém-tartalmú homogén fázisban alkalmazott társaikkal szemben az organokatalizátorok számos előnye közé tartozik az alacsony toxicitásuk, megbízható alkalmazásuk és széles pH-tartományon belüli stabilitásuk, valamint legtöbbször nem érzékenyek a levegöre és az oldószer nedvességtartalmára sem. ${ }^{2}$ Ez teszi a velük való munkát jelentősen könnyebbé, és elösegíti ipari alkalmazásukat is.

Doktori munkám során olyan új, cinkona egységet tartalmazó bifunkciós hidrogénkötés létesítésére alkalmas organokatalizátorok előállításával, alkalmazásával és visszaforgatásával foglalkoztam, melyek biológiailag aktív molekulák szintézisében az aszimmetriacentrumot kialakító lépésben enantioszelektív módon a megfelelő konfigurációjú termék keletkezését segítik elő. Ilyen reakciók a Michael-addíció, a konjugált addíció, az aza-Markovnyikov-addíció és a DielsAlder-reakció. Az általam vizsgált bifunkciós organokatalizátorok tartalmaznak hidrogénkötés-donor, illetve -akceptor egységeket, melyek segítségével egyidejüleg képesek mind a nukleofileket, mind pedig az elektrofileket aktiválni.

A fentiekben bemutatott organokatalizátorok előállítása időigényes, költséges, és sokszor a reakció végén nem visszanyerhetők. Ennek a problémának a kiküszöbölésére megkíséreltem valamennyi elöállított organokatalizátor visszaforgatását. Ehhez az úgynevezett szerves oldószeres nanomembránszürést (OSN), és a szilárd polimerhez (poli(glicidil-metakrilát), PGMA) történő rögzítést alkalmaztam.
Az organokatalízist régóta alkalmazzák a szerves szintézisekben. Bredig és Fiske már 1912-ben lejegyezte a hidrogén-cianid benzaldehidre történő aszimmetrikus addícióját kinin és kinidin jelenlétében. ${ }^{3}$ Kiemelkedően fontos eredmény volt az organokatalízis történetében az 1970-es években publikált Hajós-Parrish-Eder-Sauer-Wiechertreakció (1. ábra), amely lehetővé tette a szteroid-szintézisek alapanyagának, a Wieland-Miescher-ketonnak az enantioszelektív előállítását L-prolin segítségével. ${ }^{4}$

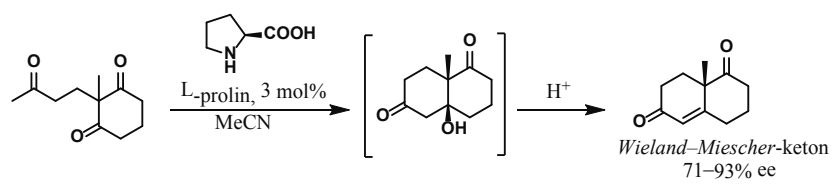

1. ábra. A Hajós-Parrish-Eder-Sauer-Wiechert-reakció.

A sikeres eredmények ellenére mintegy 20 éven keresztül az aszimmetrikus organokatalízis nem került elötérbe. A 2000es évek elején MacMillan, List és Barbas munkája irányította a figyelmet erre a területre, amit jelentős mértékben segített a zöld kémiai szemlélet, mivel megnövekedett az igény a környezetet kevésbé terhelő vegyipari eljárásokra. Továbbá az ez idő tájt már elterjedt királis HPLC jelentősen lerövidítette az enantioszelektivitás mértékének meghatározását. Innentől kezdve számos katalizátorcsalád előállítása, alkalmazása és müködésük megismerése tette a területet önálló diszciplínává az enantioszelektív szintézisek családján belül.

Az enantiomertiszta vegyületek előállítására jellemző, így a királis organokatalizátorok előállítására is, hogy legygyakrabban a „királis készletből” választunk alapanyagot. Ez mind gazdasági, mind pedig zöld kémiai megfontolások alapján is kedvező lehet. Ezért a kereskedelmi forgalomból könnyen hozzáférhető, több aszimmetriacentrumot is tartalmazó kinint és származékait elterjedten választják organokatalizátorok építőelemeként. Előnyük, hogy ezen molekulák több helyen is könnyen módosíthatók. Ezen felül megfigyelték, hogy amennyiben a katalitikus aktivitásért felelős molekularész konfigurációja ellentétes, úgy a királis indukció során az adott reakcióban az ellenkező enantiomer keletkezése lehet a preferált, így alkalmazásukkor az aszimmetrikus reakciók finomhangolására van lehetőség. ${ }^{5}$

A bifunkciós hidrogénkötés organokatalizátorok kovalens intermediert nem képző, csak másodlagos kölcsönhatásokkal operáló katalizátorok. Ezek felépítését az jellemzi,

\footnotetext{
Nagy Sándor azonos című PhD értekezéséhez kapcsolódó tézisfüzet alapján készült.

Tel.: +36 1463 2229; fax: +36 1463 3297; e-mail: jkupai@mail.bme.hu
} 
hogy az aktív centrumban egyszerre található Lewis-savas és -bázikus csoport is, melyek nem csak aktiválják, hanem térben is orientálják a szubsztrátokat. ${ }^{6}$ Két hidrogénkötés erőssége együttesen megegyezhet akár egy kovalens kötés erősségével is.? Tipikusan ilyen katalizátorok a cinkona-tiokarbamidok és -négyzetamidok. A tiokarbamid és négyzetamid egységek NH csoportjai hidrogénkötés-donorként, míg a bázikus kinuklidin nitrogénatom bázisként, hidrogénkötés-akceptorként viselkedhet.

Manapság a vegyipar minden ágába begyürüzött a zöld és a fenntartható kémia. Így megannyi módszert dolgoztak ki az organokatalizátorok olcsó, környezetbarát alkalmazására, kiemelt hangsúlyt fektetve az újra felhasználásra. A visszaforgatás történhet szerves oldószeres nanoszüréssel, oldható, vagy oldhatatlan hordozóhoz történő rögzítéssel, kicsapatásos módszerekkel, vagy többfázisú rendszerek alkalmazásával. ${ }^{8,9}$

\section{Eredmények}

\subsection{Három új, bifunkciós glükóz-tiokarbamid organokatalizátor előállítása és alkalmazása aszimmetrikus Michael-addícióban ${ }^{10}$}

Doktori munkám során a bifunkciós organokatalizátorok közül elsőként királis tiokarbamidok szintézisével és alkalmazásával foglalkoztam. Elöállítottam három új, glükóz-egységet tartalmazó organokatalizátort (2. ábra). Ezen bifunkciós organokatalizátorok hidrogénkötés-donor egységei a tiokarbamid egység NH csoportjai, míg a hozzájuk kapcsolódó bázikus jellegü piridinszármazékok, illetve a cinkonavázon található bázikus kinuklidin nitrogénatom töltik be a hidrogénkötés-akceptor szerepét. Ezek a másodrendủ kölcsönhatások hozzájárulhatnak a szelektivitáshoz vagy enantiomerfelismeréshez. ${ }^{11}$ Királis indukciót biztosító szerkezeti elemként a glükóz-, illetve cinkona-egységeket választottam.

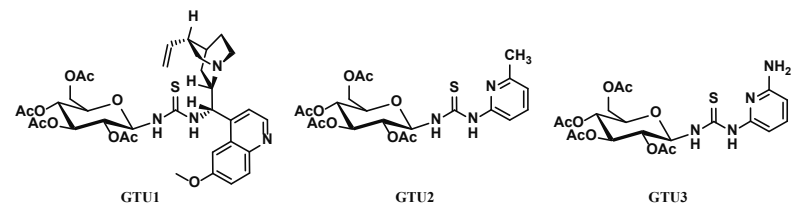

2. ábra. Új, glükóz-egységet tartalmazó organokatalizátorok.

A katalizátorok szintézisét D-glükózból (1) kiindulva valósítottam meg. A glükózt a 3. ábrán látható két módon $(2 \mathrm{~A}$ és $2 B$ ) alakítottam acetobróm-glükózzá (2), melyből előállítottam a katalizátorok kulcsintermedierjét, a peracetil-glükóz-izotiocianátot (3) (3. ábra).

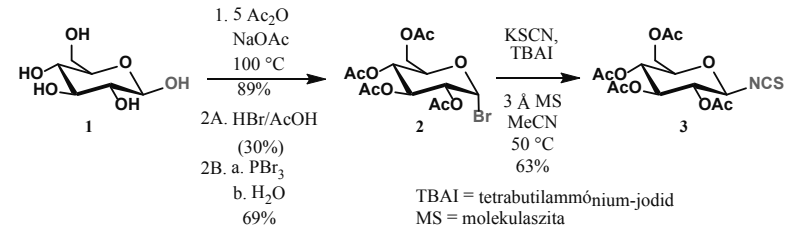

3. ábra. Tetraacetil-glükóz-izotiocianát (3) elóállítása.
A cinkona-egység beépítéséhez hidrokininből (HQ) indultam ki, melynek a 9-es pozíciójába aminocsoportot építettem be egy inverzióval járó Mitsunobu-reakcióban képződő azid intermedier Staudinger-reakciójával (4. ábra). A cinkona-amin (HQ-N) demetilezésével kialakítottam a molekulán egy újabb, potenciálisan hidrogénkötés-donorként viselkedő egységet, egy fenolos $\mathrm{OH}$ csoportot.

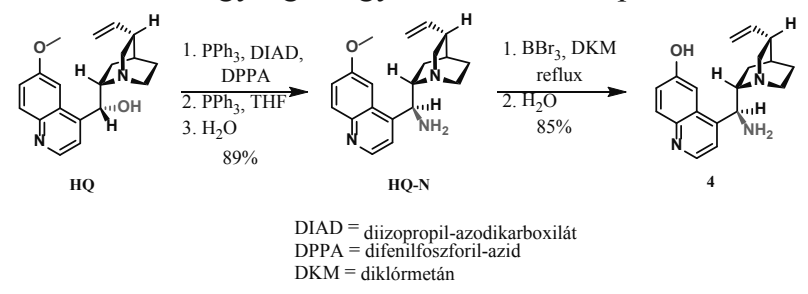

4. ábra. Demetilezett cinkona-amin (4) elobállítása.

A megfelelő aminokat (4-6) a peracetil-glükóz-izotiocianáttal (3) reagáltatva jutottam a kívánt katalizátorokhoz (GTU1-3, 5. ábra).

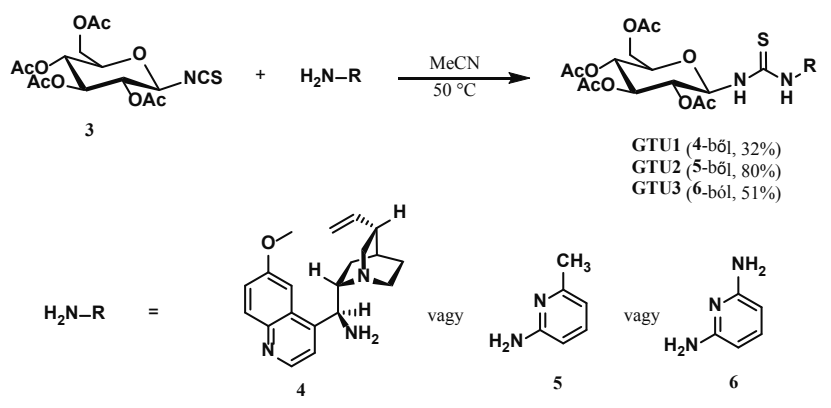

5. ábra. A tiokarbamid katalizátorok (GTU1-3) elóállítása.

A katalizátorokat pentán-2,4-dion (7) és transz- $\beta$-nitrosztirol (8) Michael-addíciós reakciójában alkalmaztam 1 mol\% mennyiségben, három különbözö oldószerben. Habár a glükóz-egység által mindhárom katalizátor tartalmaz több aszimmetriacentrumot, az eredmények azt tükrözik, hogy szükség van a cinkona szerkezeti egységre, ugyanis egyéb esetekben racemát keletkezett. Ezért az 1. táblázatban csak a cinkonavázat tartalmazó katalizátorral elért eredményeket tüntettem fel. Mivel még a cinkonavázat tartalmazó katalizátorral (GTU1) is csak alacsonyközepes enantioszelektivitást lehet elérni, így elmondható, hogy az eredmények javítása céljából további optimalizálásra lehet szükség.

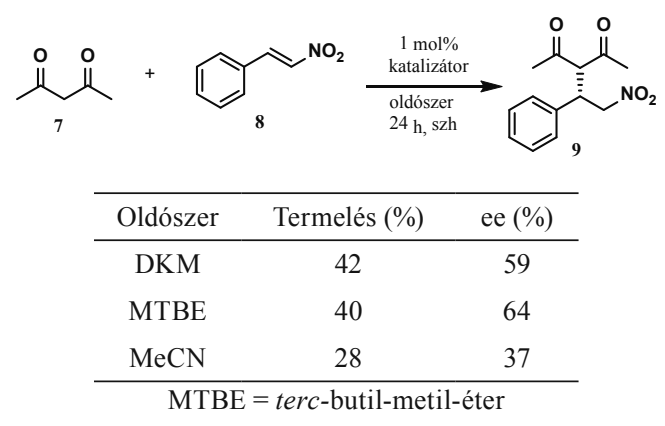

1. táblázat. A cinkona-glükóz-tiokarbamid organokatalizátor (GTU1) alkalmazása aszimmetrikus Michael-addícióban. 


\subsection{A kinuklidingyürün etil-, vinil- vagy etinilcsoportot tartalmazó cinkona-katalizátorok összehasonlítása ${ }^{12}$}

A cinkona alapú katalizátorokat a kereskedelemben kapható kininből (Q) kiindulva állítottuk elö. Ezt elsőként katalitikus hidrogénezési lépésben hidrokininné (HQ) alakítottunk át. A didehidrokininhez (DQ) a kininből (Q) kétlépéses reakcióban jutottunk el: brómaddíciót követő hidrogén-bromid eliminációval. ${ }^{13}$ Ezekből a hidroxiszármazékokból (HQ, Q, DQ) a már korábban ismertetett eljárással Mitsunobureakciót követő Staudinger-reakció segítségével állítottuk elő a cinkona-amin származékokat $(\mathbf{H Q}-\mathbf{N}, \mathbf{Q}-\mathbf{N}, \mathbf{D Q}-\mathbf{N}){ }^{14}$ Ezt következően a tiokarbamid-származékokat (HQ-TU, Q-TU, DQ-TU) a megfelelő cinkona-aminok (HQ-N, Q-N, DQ-N) és a $\mathbf{1 0}$ izotiocianát reakciójával nyertük. ${ }^{15}{ }^{16}$ Végül, ugyanezen cinkona-aminok és a $\mathbf{1 1}$ félnégyzetamid reakciójával jutottunk a megfelelő cinkona-négyzetamidokhoz (HQ-SQ, Q-SQ, DQ-SQ, 6. ábra). ${ }^{17}$

Az előállításukat követően szerettük volna mélyrehatóbban tanulmányozni és értelmezni a későbbi eredményeket, ezért megmértük a $\mathrm{p} K_{\mathrm{a}}$ értéküket több oldószerben, azaz mind a kinuklidin nitrogénatom bázikusságáról (2. táblázat), mind pedig a kétszeres hidrogénkötés-donor katalizátoregységek NH csoportjainak (3. táblázat) savasságáról számszerü értékekhez jutottunk (az egyszerüség kedvéért itt csak a vízben mért eredményeket mutatom be).

Jól látható, hogy a kinuklidinen található szubsztituens befolyásolja a bázikus nitrogén $\mathrm{p} K_{\mathrm{a}}$ értékét, a telítettséggel nő a bázicitás (akár 1,7 p $K_{\mathrm{a}}$ érték különbség is lehet). Feltehetően a szubsztituens és az NH csoportok közti nagy távolság miatt a szubsztituensek telítettsége nem volt jelentős hatással az NH csoportok savasságára.

\begin{tabular}{cccc}
\hline Katalizátor & $\mathrm{p} K_{\mathrm{a}}$ & Katalizátor & $\mathrm{p} K_{\mathrm{a}}$ \\
\hline HQ & 9,10 & HQ-SQ & 7,86 \\
$\mathbf{Q}$ & 8,52 & Q-SQ & 6,95 \\
DQ & 7,40 & DQ-SQ & 6,13 \\
\hline HQ-N & 9,71 & HQ-TU & 8,61 \\
Q-N & 9,10 & Q-TU & 8,06 \\
DQ-N & 8,10 & DQ-TU & 7,02 \\
\hline
\end{tabular}

2. táblázat. A kinuklidin nitrogénatom konjugált savformájának vízben mért $\mathrm{p} K_{\mathrm{a}}$ értékei az egyes katalizátorok esetén.

\begin{tabular}{cccc}
\hline Katalizátor & $\mathrm{p} K_{\mathrm{a}}$ & Katalizátor & $\mathrm{p} K_{\mathrm{a}}$ \\
\hline HQ-SQ & 9,57 & HQ-TU & 10,87 \\
Q-SQ & 9,29 & Q-TU & 10,84 \\
DQ-SQ & 9,20 & DQ-TU & 10,78 \\
\hline
\end{tabular}

3. táblázat. A kétszeres hidrogénkötést tartalmazó egységek NH csoportjainak vízben mért $\mathrm{p} K_{\mathrm{a}}$ értékei a tiokarbamid és négyzetamid típusú katalizátorok esetén.

Azért, hogy az így kapott $\mathrm{p} K_{\mathrm{a}}$ értékek és a katalizátorok teljesítőképessége közt tényleges korrelációt fedezzünk fel, az előállított katalizátorokat pentán-2,4-dion (7) és transz- $\beta$-nitrosztirol (8) Michael-addíciós reakciójában alkalmaztuk (7. ábra). Mivel a legjobb eredményeket tiokarbamid és négyzetamid katalizátorokkal értük el, így a 8. ábrán csupán ezeket mutatom be.

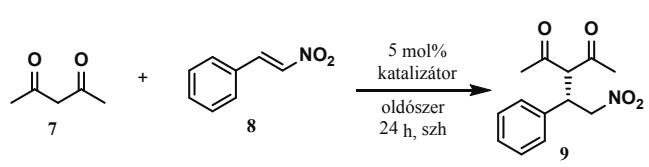

7. ábra. Pentán-2,4-dion és transz- $\beta$-nitrosztirol Michael-addíciós reakciója.

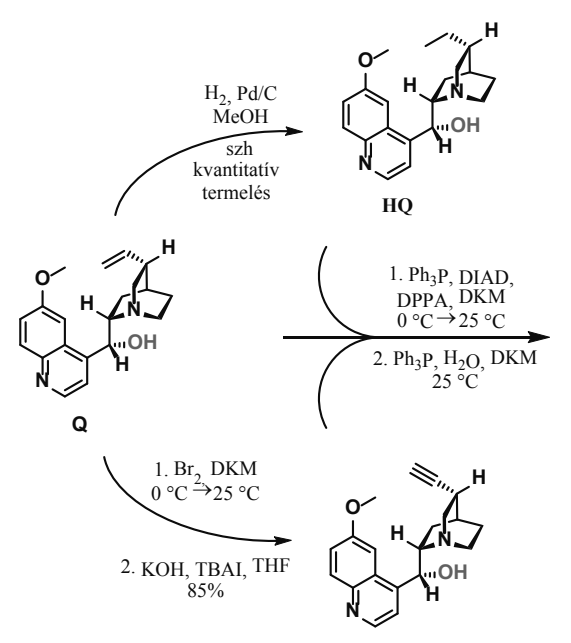

DQ

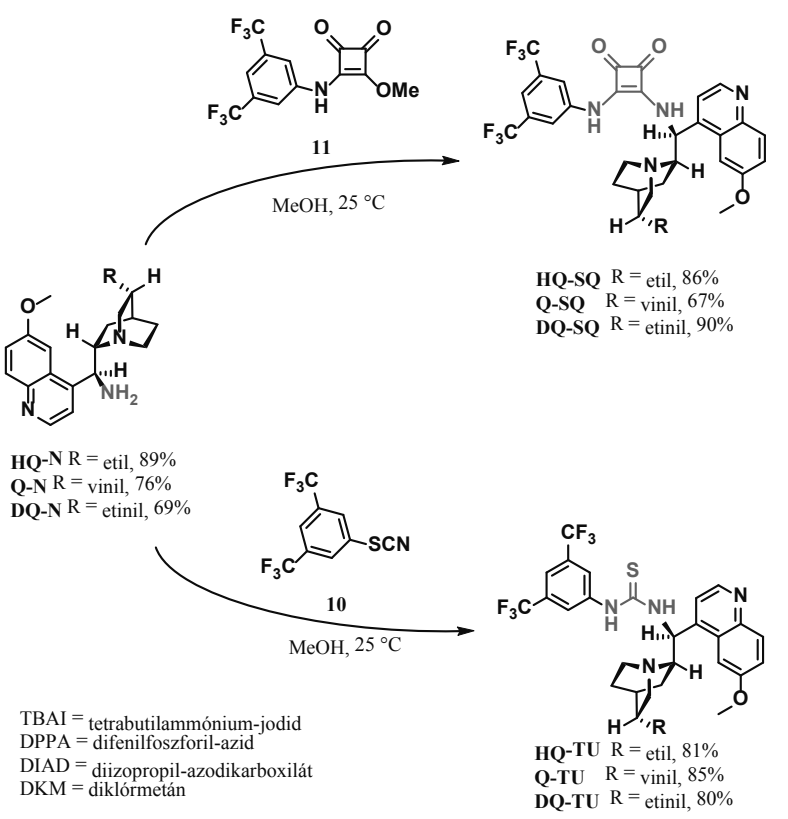

6. ábra. Cinkona-alapú organokatalizátorok szintézise a kereskedelmi forgalomban elérhető kininből (Q) kiindulva. 
A)

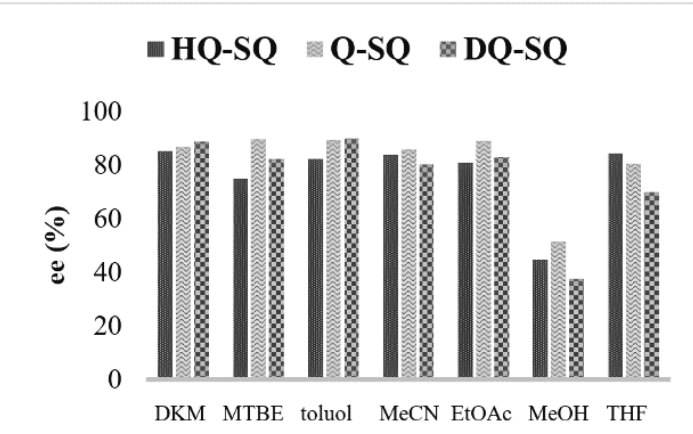

B)

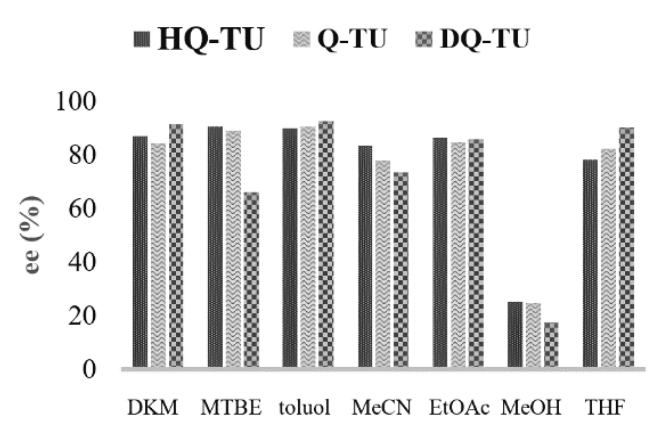

8. ábra. Különböző oldószerekben mért enantioszelektivitási értékek négyzetamidok (A) és tiokarbamidok (B) által katalizált Michael-addíciós reakcióban.

A termelés a metanolon kívül minden oldószerben közel $100 \%$ volt, így ezen értékekben jelentős különbség nincs a katalizátorok közt. A metanol, mint prótikus oldószer feltehetően destabilizálja a szubsztrátok és a katalizátor között létrejövő hidrogénhidas kölcsönhatást, ez okozhatta az alacsonyabb termelést és enantioszelektivitást. Oldószertől függően az enantioszelektivitásban van némi eltérés a kinuklidinen eltérő telítettségü szubsztituenst tartalmazó katalizátorok között, azonban korrelációt nem véltem felfedezni az eredményekben. Több esetben elmondható, hogy van olyan oldószer, melyben egyes tiokarbamidok és van olyan, melyben inkább a négyzetamidok adnak nagyobb enantioszelektivitási értékeket. Ezek alapján állíthatjuk, hogy bár kis módosításokkal újabb és újabb katalizátorok hozhatók létre, azonban ezen módosítások nem feltétlenül indokoltak, amennyiben nem adnak jobb eredményt, vagy nem szélesítik ki a reakciók körét, amelyekben a katalizátor alkalmazható. Esetünkben a legkönnyebben hozzáférhető kininből kiinduló katalizátorok előállítása célszerü (Q-SQ, Q-TU), amennyiben aszimmetrikus Michael-addícióban szeretnénk azokat alkalmazni.

\subsection{Multisztereogén négyzetamidok előállítása és alkalmazása aszimmetrikus reakciókban ${ }^{18}$}

A négyzetamidokra és tiokarbamidokra jellemző, hogy hidrogénkötés-donorként viselkednek organokatalizátorok szerkezeti egységeként. A tionégyzetamidok aszimmetrikus organokatalizátorként történő alkalmazására azonban eddig még csupán kevés példa található a szakirodalomban. ${ }^{19-23}$

Minél savasabb egy ilyen egység, annál erősebb hidrogénkötés-donorként viselkedhet. A tionégyzetamidok azon kívül, hogy lipofilebbek, alacsonyabb $\mathrm{p} K_{\mathrm{a}}$ értékkel rendelkeznek, mint a megfelelő négyzetamidok. Ebből kifolyólag elképzelhető, hogy másmilyen viselkedést várhatunk tőlük aszimmetrikus reakciókban történő alkalmazásukkor. Ezt kívántam vizsgálni binaftil-cinkona-(tio)négyzetamidok ( 9 . $a ́ b r a)$ előállításával és alkalmazásával.
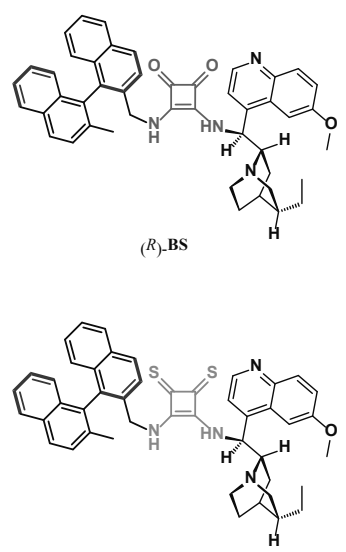

$(R)-\mathbf{B T S}$

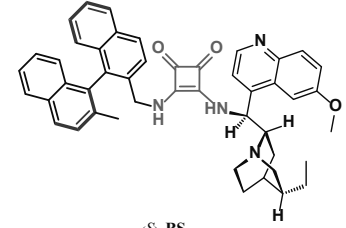

(S)-BS

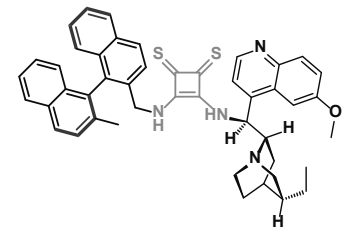

(S)-BTS
9. ábra. Az eloóllított binaftil-cinkona-(tio)négyzetamidok.

A katalizátorok binaftil egységeit a királis aminometil-binaftalinok $[(R)$-12, $(S)$-12] segítségével építettem be a molekulákba (10. ábra). Az egység szintézisét enantiomertiszta dimetilbinaftilból $[(R)-13,(S)-13]$ kiindulva valósítottam meg.

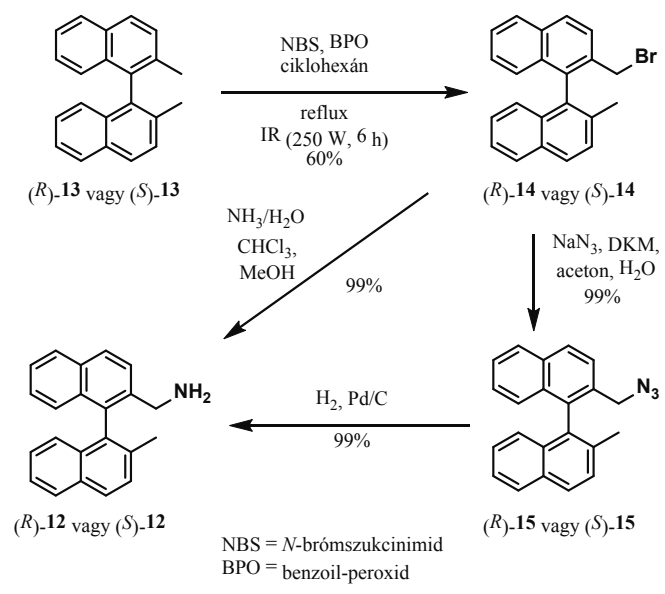

10. ábra. Aminometilbinaftalinok $[(R)-12,(S)$-12] előállítása.

A cinkona-amin (HQ-N) és a négyzetsavészterek (16a vagy 16b) reakciójából cinkona félnégyzetamidokhoz (17a vagy 17b) jutottam (11. ábra). Ezt reagáltatva az aminometil binaftalinokkal $[(R)-12,(S)$-12] jutottam a megfelelő „oxo” $[(R)$-BS és $(S)$-BS $]$ katalizátorokhoz, melyeket tetrafoszfor-dekaszulfidnak piridinnel alkotott komplexével reagáltatva a megfelelö ditioszármazékokat [(R)-BTS és $(S)$-BTS $]$ kaptam (11. ábra). 


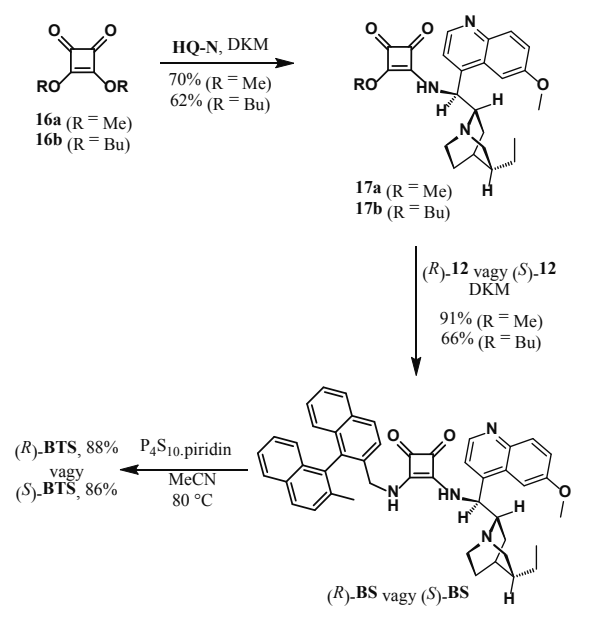

11. ábra. Multisztereogén binaftil-cinkona-(tio)négyzetamidok előállítása.

Ezen katalizátorokat pentán-2,4-dion (7) és transz- $\beta$-nitrosztirol (8) reakciójában alkalmaztam elsőként, különböző oldószerekben. Azt találtam, hogy etil-acetát oldószerben alkalmazva őket még 0,2 mol\% mennyiségben is kiváló termelési (akár 96\%) és enantiomerfelesleg (akár 98\%) értékek érhetők el. Mivel ezen a ponton nagy különbséget nem tapasztaltam a négy katalizátor hatékonysága között (annak ellenére, hogy eltérö konfigurációjú binaftil-egységeket tartalmaznak), elvégeztem velük a hennotánsav (18) és egy $\beta, \gamma$-telítetlen $\alpha$-ketoészter (19) konjugált addícióját (4. táblázat), valamint az aza-Diels-Alder-reakciót egy 2-sziloxidién származék (21) és a benzilidén-anilin (22) között (12. ábra).

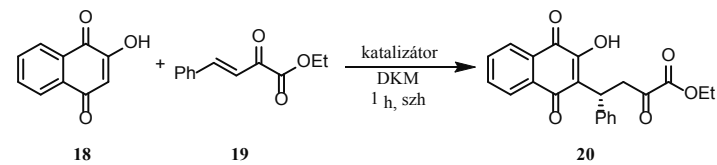

\begin{tabular}{|c|c|c|c|}
\hline Katalizátor & $\begin{array}{c}\text { Katalizátor meny- } \\
\text { nyisége [mol\%] }\end{array}$ & $\begin{array}{c}\text { Termelés } \\
{[\%]}\end{array}$ & ee $[\%]$ \\
\hline$(R)-\mathbf{B S}$ & 10 & 93 & 79 \\
\hline$(R)-\mathbf{B S}$ & 5 & 98 & 83 \\
\hline$(R)-\mathbf{B S}$ & 1 & 74 & 83 \\
\hline$(R)$-BTS & 10 & 89 & 91 \\
\hline$(R)$-BTS & 5 & 93 & 92 \\
\hline$(R)$-BTS & 1 & 46 & 88 \\
\hline$(S)$-BS & 10 & 100 & 83 \\
\hline$(S)$ - BS & 5 & 100 & 84 \\
\hline$(S)$-BS & 1 & 73 & 79 \\
\hline$(S)$-BTS & 10 & 100 & 88 \\
\hline$(S)$-BTS & 5 & 100 & 89 \\
\hline$(S)$-BTS & 1 & 100 & 90 \\
\hline
\end{tabular}

4. táblázat. A katalizátorok alkalmazása konjugált addíciós reakcióban.

Konjugált addíció esetén a különbség az enantioszelektivitási értékekben mutatkozott meg. A tionégyzetamidok minden esetben nagyobb enantioszelektivitással szolgáltat- ták az adduktot. Elmondható, hogy az $S$ konfigurációjú binaftil-egység beépítése célszerűbb, ugyanis közel hasonló szelektivitással, de jobb termeléssel szolgáltatta a terméket, kiemelve a $(S)$ BTS-t, mellyel még $1 \mathrm{~mol} \%$ esetén is kvantitatív termelés érhető el kitűnő szelektivitás mellett.

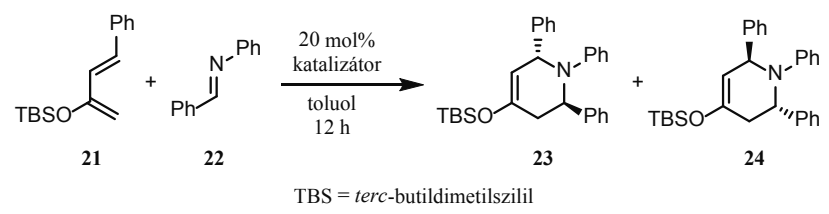

12. ábra. Benzilidén-anilin (22) és egy 2-sziloxidién (21) aza-Diels-Alder-reakciója.

Az aza-Diels-Alder-reakció esetén csak a $(R)$-BTS tionégyzetamid szolgáltatta jó termeléssel $(80 \%)$ az adduktot, 5,4:1 diasztereomeraránnyal, egyéb esetekben nem tapasztaltunk reakciót.

Ezen reakciókban elért eredmények alapján elmondható, hogy a tionégyzetamidok ígéretes katalizátorai lehetnek további aszimmetrikus reakcióknak.

\subsection{Az aza-Markovnyikov-addíció megvalósítása környezetbarátabb módon cinkona-származékok alkalmazásával és visszaforgatásával ${ }^{24}$}

Az aza-Markovnyikov-addíció hasznos szén-nitrogén kötést kialakító reakció, mely általában aromás aminok és elektronszívó csoportot tartalmazó olefinek reakciójakor valósul meg báziskatalízis hatására. Az ilyen módon kapott vegyületek gyakran biológiailag aktív tulajdonsággal rendelkeznek: akaricidekként, ${ }^{25}$ mikrobaellenes, ${ }^{26}$ vagy tumorellenes ${ }^{27}$ szerekként alkalmazzák őket.

Az aza-Markovnyikov-addíciót a szakirodalomban gyakran magasabb hőmérsékleten, nagy katalizátor, illetve reagens felesleg alkalmazásával írják le, mindezt kevésbé „zöld” oldószerekben, mint pl. a dimetilformamid (DMF). ${ }^{28,29}$ Ezen paraméterek hatását imidazol (25), illetve benzimidazol (26) és vinil-acetát (27) addíciós reakciójában vizsgáltam (13. ábra). Csökkentettem a hőmérsékletet $50{ }^{\circ} \mathrm{C}$-ról $25^{\circ} \mathrm{C}$-ra, majd a katalizátor mennyiségét is $30 \mathrm{~mol} \%$-ról $5 \mathrm{~mol} \%$-ra redukáltam. Ezt követően a reagens mennyiségét 8 ekvivalensröl 1,2 ekvivalensre csökkentettem, végül pedig az oldószert DMF-röl acetonitrilre cseréltem. Sajnos a termelések értékei is visszaestek: imidazolból kiindulva 61\%-ról 44\%-ra, benzimidazolból kiindulva 65\%-ról 48\%-ra. Kiszámolva a Sheldon-féle E-faktor értékeket (melynél környezetvédelmi szempontból elönyös a minél kisebb érték), azok több mint felével csökkentek, így az általam alkalmazott körülmények környezetbarát alternatívái lehetnek a szakirodalomban közölteknek.

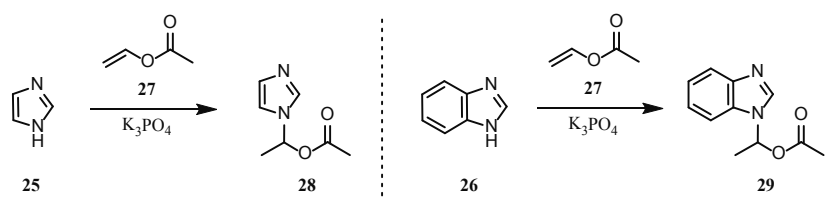

13. ábra. Imidazol (25), illetve benzimidazol (26) és vinil-acetát (27) aza-Markovnyikov-reakciói. 
Elvégeztem ezen reakciókat organokatalitikus módon is, cinkona-származékokat alkalmazva katalizátorként. Ehhez hidrokinint (HQ), cinkona-amint (HQ-N) és cinkona-négyzetamidot (HQ-SQ) használtam (6. ábra, 3. oldal).

A legjobb termeléseket cinkona-amin (HQ-N) alkalmazásával értem el ( $95 \%$ a $\mathbf{2 8}$ addukt és $92 \%$ a 29 addukt esetén), mely az optimalizált körülmények között közel kétszerese az irodalmi katalizátor $\left(\mathrm{K}_{3} \mathrm{PO}_{4}\right)$ alkalmazásakor kapott termelési értékeknek.

Az aza-Markovnyikov-addíciót elvégeztem ezen katalizátorokat alkalmazva más szubsztrátok (pirazol, triazol) és reagens (terc-butil-4-vinilbenzoát) felhasználásával is, azonban az eredmény azt mutatta, hogy az általam alkalmazott szubsztrátoknak jelentős hatásuk nincs a reakció kimenetelére. Sajnos az organokatalizátorok alkalmazásakor kapott termékek racémnek bizonyultak.

Még környezetbarátabbá téve az aza-Markovnyikov-reakciót, az úgynevezett OSN technikát (szerves oldószeres nanoszürés) használtam a reakciók feldolgozására. A technika során egy homogén szerves oldat nanoszürése valósul meg nagyobb nyomás (10-30 bar) ellenében, mely során a megfelelő pórusméretű nanomembrán megválasztásával megvalósítható, hogy a kisebb molekulák a folyamat végén a permeátumba, míg a nagyobb molekulák a retentátumba kerüljenek.

Ezen technikát optimalizálva imidazol (25) és vinil-acetát (27) reakciója esetén a membrán általi visszatartások a kiindulási anyagokra, termékre és a katalizátorokra a 14. ábrán láthatók. Az eredmények azt mutatják, hogy ezen katalizátorok visszatartása közel 100\%, így elmondható, hogy szinte teljes mértékben visszaforgathatók az OSN technika alkalmazásával.

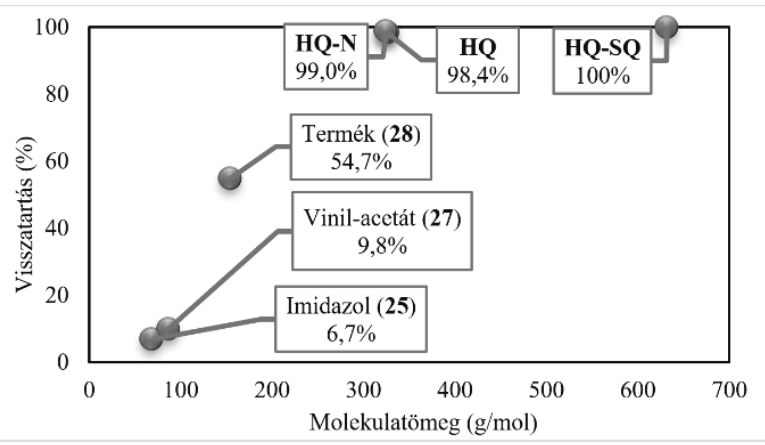

14. ábra. Visszatartási értékek az aza-Markovnyikov-reakció kiindulási anyagaira, termékére és a használt katalizátorokra.

\subsection{PGMA-hoz rögzített cinkona-négyzetamid organokatalizátor előállítása és alkalmazása ${ }^{30}$}

A PGMA, azaz poli(glicidil-metakrilát) egy olyan polimer, mely epoxicsoportokat tartalmaz, melyek száma mérésekkel nagy pontossággal meghatározható. ${ }^{31}$ Epoxicsoportjainak köszönhetően könnyen reakcióba vihető nukleofilekkel, mint például primer aminokkal. Ebből kifolyólag, és mivel sok aszimmetrikus reakcióban inert anyagként viselkedik, alkalmas katalizátorhordozónak.

Nagy előnyei közé tartozik, hogy előállítható diszperziós polimerizációval, mely során szük méreteloszlású, gömb alakú, 1-5 mikronos szemcsékhez juthatunk, mely szemcsék méretét a polimerizáció körülményeinek változtatásával befolyásolhatjuk. Habár ezen szemcsék bizonyos, gyakran használt szerves oldószerekben oldhatók, utólagos térhálósítással ez az oldhatóság nagy mértékben csökkenthető. Az ilyen szemcsékhez rögzített katalizátor centrifugálással vagy szüréssel (szemcsemérettől függően) visszanyerhető a reakcióelegyből, illetve oszlopba töltve folyamatos áramlású rendszerekben alkalmazható. A PGMA-t diszperziós polimerizációval állítottuk elő glicidil-metakrilátból kiindulva (15. ábra), mely során 1,36 mikronos, gömb alakú, szük szemcseméreteloszlással rendelkező polimerhez jutottunk. Az így kapott polimert etilénglikol-dimetakriláttal (EGDMA) történő utólagos térhálósításával tettük ellenállóvá mind az oldhatósággal, mind pedig mechanikus behatásokkal szemben, hogy amennyiben lehet, alkalmazni tudjuk folyamatos áramlású rendszerekben is.

A)

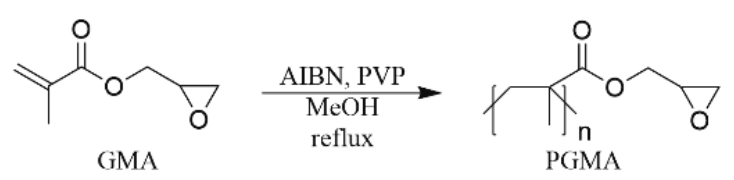

AIBN $=$ azo-bisz-izobutironitril $\mathrm{PVP}=$ poli(vinil-pirrolidon)

B)

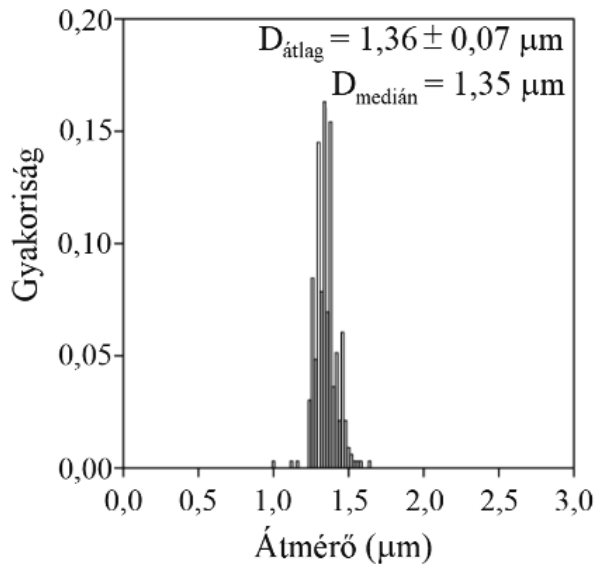

C)

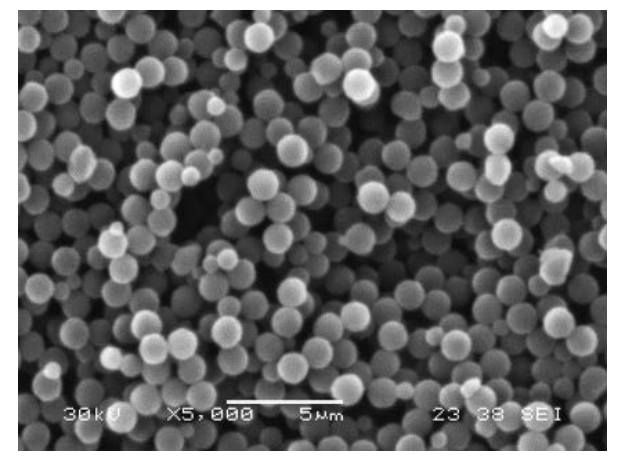

15. ábra. PGMA előállítása (A), az így nyert szemcsék méreteloszlása (B) és SEM-felvétele (C). 
Mivel bifunkciós cinkona-négyzetamid organokatalizátorokat terveztünk rögzíteni a PGMA-hoz, ehhez szükséges volt úgy módosítani a katalizátorokat, hogy tartalmazzanak primer aminocsoportot, mely készségesen reagál epoxicsoportokkal. Ehhez három különböző prekatalizátort állítottunk elő, mely során a különféle linkeren keresztül a cinkona-négyzetamid más-más pozíciójába építettünk be primer aminocsoportot.

A kinuklidinvázon történő módosítást a már bemutatott cinkona-négyzetamid didehidrokinin származékából (DQ-SQ) kiindulva valósítottam meg azid-alkin cikloaddíció segítségével (16. ábra). Így egy aromás, kevésbé flexibilis linkert építettem be a $\mathbf{3 1}$ katalizátorba.

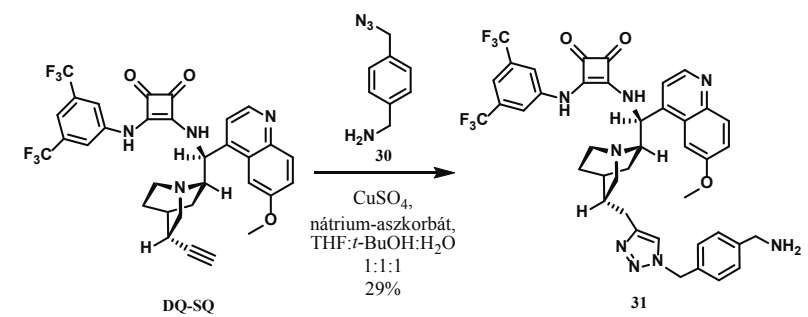

16. ábra. Aromás linkeren keresztüli primer aminocsoporttal ellátott 31 cinkona-négyzetamid előállítása.

A kinolinvázon történő módosítást a 32 kinolingyürün szabad hidroxilcsoportot tartalmazó négyzetamidból kiindulva valósítottam meg. Ezt reagáltatva $O$-toluolszulfonil- $N$-Boc-etanol-aminnal (33), majd az így kapott termékből a védőcsoportot eltávolítva jutottam az etilén linkeren keresztül aminocsoporttal módosított prekatalizátorhoz $(\mathbf{3 4}, 17$. ábra $)$.
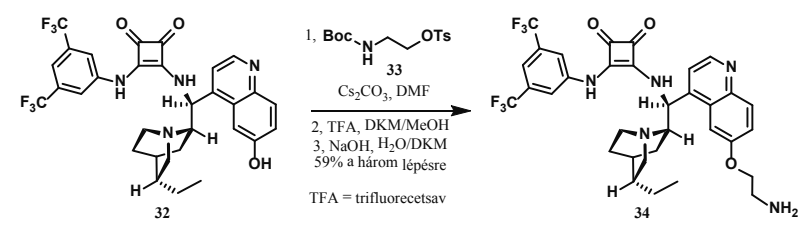

17. ábra. Etilén linkeren keresztüli primer aminocsoporttal ellátott cinkona-négyzetamid (34) előállítása.

Végül a harmadik prekatalizátort (37) úgy állítottam elő, hogy a négyzetamid egységet egy hosszabb, flexibilisebb linkerrel módosítottam. A kereskedelemböl beszerezhetö mono- $N$-Boc-1,6-diaminohexán (35) és négyzetsav-dimetilészter (16a) reakciójával a $\mathbf{3 6}$ félnégyzetamidot állítottam elö, mely utóbbit cinkona-aminnal (HQ-N) reagáltattam, majd a védőcsoportot eltávolítottam, így jutottam a szabad aminhoz $(\mathbf{3 7}, 18$. ábra).

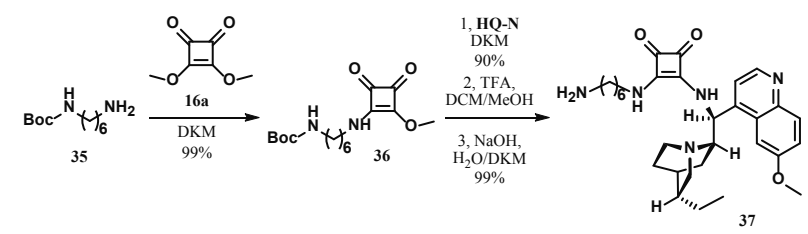

18. ábra. A PGMA-hoz rögzítendő cinkona-négyzetamid organokatalizátor (37) előállítása.
A szintézis utolsó lépéseként a primer aminocsoportot tartalmazó 31, 34 és 37 cinkona-származékok térhálósított PGMA-hoz történő rögzítése következett (19. ábra). A reakciót metanolban végeztem, három szilárd hordozóhoz rögzített új cinkona-négyzetamid organokatalizátorhoz $(\mathbf{C 1}, \mathbf{C 2}$ és C3) jutva. A hordozóhoz kötött katalizátorok mennyiségét energiadiszperzív röntgenspektroszkópia (EDX) alkalmazásával határoztuk meg.

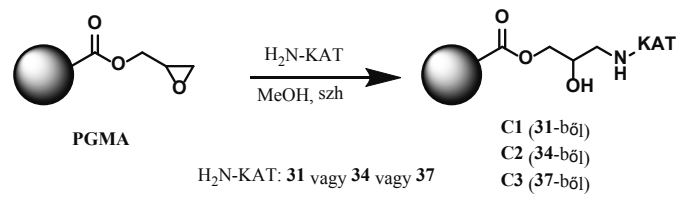

19. ábra. A prekatalizátorok PGMA-hoz rögzítésének sematikus ábrázolása.

Az így kapott katalizátorokat pentán-2,4-dion (8) és transz- $\beta$-nitrosztirol (9) reakciójában próbáltam ki. A katalizátorokat centrifugálás segítségével visszaforgattam, majd azonos körülmények közt még négyszer alkalmaztam ugyanazon Michael-addícióban. A legmagasabb enantiomerfelesleg értékeket ( $96 \%$ ee) a C2 katalizátorral értem el $0{ }^{\circ} \mathrm{C}$-on. Ez az érték a katalizátor egymás után ötször történt felhasználását követően sem változott, de a termelés 8\%-os csökkenését tapasztaltuk (5. táblázat).

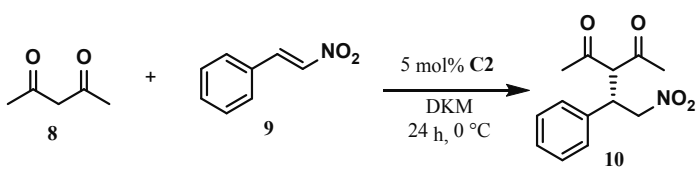

\begin{tabular}{ccc}
\hline Alkalmazások száma & Termelés [\%] & ee [\%] \\
\hline 1 & 84 & 96 \\
2 & 80 & 96 \\
3 & 80 & 96 \\
4 & 75 & 96 \\
5 & 76 & 96 \\
\hline
\end{tabular}

5. táblázat. A C2 rögzített organokatalizátor alkalmazása aszimmetrikus Michael-addícióban.

Az enantiomerfelesleg értékek a rögzített katalizátor esetén közel azonosak, mint a rögzítetlen cinkona-négyzetamidok esetén. Ezek alapján elmondható, hogy a leghatékonyabb rögzítési mód esetünkben a kinolingyürün keresztüli etilén-linkerrel történő rögzítés.

\section{Kísérleti módszerek}

A szintetikus munka során a preparatív szerves kémia módszereit alkalmaztuk. A reakciók előrehaladását vékonyréteg-kromatográfiával, illetve LC-MS technika segítségével követtük. Az anyagok tisztítására oszlopkromatográfiás módszereket, preparatív vékonyréteg-kromatográfiát, illetve átkristályosítást alkalmaztunk. Az anyagok tisztaságának ellenőrzésére vékonyréteg-kromatográfiát, olvadás- 
pontmérést, optikai forgatóképesség-mérést, illetve királis HPLC-t használtunk. Az előállított vegyületek összetételét, szerkezetét spektroszkópiai módszerekkel (IR, ${ }^{1} \mathrm{H},{ }^{13} \mathrm{C}$, különféle 2D NMR-es technikák, MS, HRMS, elemanalízis) igazoltuk. A membránszeparációs müveleteket Dr. Székely György együttműködésével a Manchesteri Egyetemen végeztük.

\section{4. Összefoglalás}

Munkám során olyan cinkona-alapú organokatalizátorok előállításával és alkalmazásával foglalkoztam, amelyek felhasználhatók a gyógyszeriparban széles körben alkalmazott aszimmetrikus reakciókban. Ilyen reakciók a Michaeladdíció, aza-Markovnyikov-, aza-Diels-Alder- és konjugált addíciós reakciók. Ezen reakciók aszimmetrikus megvalósítása a rezolválásnál környezetbarátabb és költséghatékonyabb megoldást nyújt.

Olyan cinkonavázat tartalmazó organokatalizátorokat állítottam elö, melyeket kétszeres hidrogénkötés-donor egységekkel kapcsoltam. Ilyen egységek például a tiokarbamid, a négyzetamid és a tionégyzetamid. Ezeket a katalizátorokat aszimmetrikus reakciókban alkalmaztam kiváló termelési és enantiomerfelesleg értékek mellett. A leírt mechanizmusok alapján összefüggéseket állapítottam meg ezen molekulák sav-bázis tulajdonságai és az általuk aszimmetrikus Michael-addícióban szolgáltatott eredmények között.

Az aszimmetrikus tionégyzetamidok előállítására egy, az irodalomban ismertnél egyszerűbb szintézist dolgoztam ki, elkerülve a bomlékony köztitermékek nehézkes tisztítását. Megfigyeltem, hogy a tiokarbamidokkal és a négyzetamidokkal ellentétben csak a tionégyzetamidok képesek katalizálni az aza-Diels-Alder-reakciót.

A fent említett reakciók során az alkalmazott katalizátorokat eddig még nem forgatták vissza, ezért az általam előállított valamennyi katalizátort megpróbáltam visszanyerni, és újból felhasználni. Erre munkám során két módszert, a homogén és a heterogén visszaforgatást alkalmaztam sikeresen.

A zöld kémia elveit követve optimalizáltam az aza-Markovnikov-reakció körülményeit. Ezt a reakciót homogén fázisban hajtottam végre cinkona-alapú organokatalizátorok alkalmazásával. Miután megmértük a molekulák több különböző membránon való visszatartását szerves oldószeres nanoszürés (OSN) segítségével, találtunk egy olyan rendszert, amelyben a katalizátorok visszatartása megközelíti a 100\%-ot, azaz lehetővé teszi a katalizátorok szinte teljes visszaforgatását.

A cinkona-négyzetamidok heterogén visszaforgatását poli(glicidil-metakrilát) (PGMA) szilárd hordozóhoz való rögzítéssel valósítottam meg. Reaktív epoxicsoportjainak köszönhetően könnyen reagált olyan cinkona-négyzetamidokkal, amelyeken távtartó segítségével primer amino- csoportot alakítottam ki. A katalizátorokat aszimmetrikus Michael-addícióban alkalmaztam, és az első alkalmazásukat követően még négyszer visszaforgattam centrifugálás segítségével. Az újbóli felhasználásuk során a termelési értékek minimális csökkenését tapasztaltam, de az enantiomerfelesleg értékek változatlanok maradtak.

\section{Köszönetnyilvánítás}

A szerzők köszönik a Nemzeti Kutatási, Fejlesztési és Innovációs Hivatal (K128473), az Új Nemzeti Kiválóság Program ÚNKP-19-4-BME-415 (KJ), ÚNKP-205-BME-322 (KJ), ÚNKP-20-3-II-BME-325 (NS), a Bolyai János Kutatói Ösztöndíj (KJ), a Servier-Beregi Doktorandusz Ösztöndíj (NS), a Richter Gedeon Talentum Alapítvány doktoráns ösztöndíj (KP) és az Új Széchenyi Terv TÁMOP-4.2.1/B-09/1/KMR-2010-0002 program anyagi támogatását.
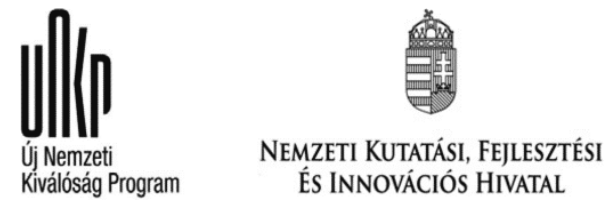

\section{Hivatkozások}

1. Dalko, P. I.; Moisan, L. Angew. Chem. Int. Ed., 2001, 40, 3726-3748. https://doi.org/10.1002/1521-3773(20011015)40:20<3726::AI D-ANIE3726 $>3$.0.CO;2-D

2. MacMillan, D. W. C. Nature, 2008, 455, 304-308. https://doi.org/10.1038/nature07367

3. Etzenbach-Effers, K.; Berkessel, A. Noncovalent Organocatalysis Based on Hydrogen Bonding: Elucidation of Reaction Paths by Computational Methods. In: List B. (eds) Asymmetric Organocatalysis. Topics in Current Chemistry, vol. 291. Springer: Berlin, Heidelberg, 2010. ISBN 978-3-642-02815-1 https://doi.org/10.1007/978-3-642-02815-1_3

4. Hajós, Z. G.; Parrish, D. R. J. Org. Chem., 1974, 39, $1615-1621$. https://doi.org/10.1021/jo00925a003

5. Krysan, D. J. Tetrahedron Lett., 1996, 37, 1375-1376. https://doi.org/10.1016/0040-4039(96)00057-3

6. Shibashaki, M.; Yoshikawa, N. Chem. Rev., 2002, 102, 2187-2210. https://doi.org/10.1021/cr010297z

7. Kelly, R.; Min, H. J. Am. Chem. Soc., 1994, 116, 7072-7080. https://doi.org/10.1021/ja00095a009

8. Cole-Hamilton, D. J. Science, 2003, 299, 1702-1706. https://doi.org/10.1126/science.1081881

9. Marchetti, P.; Jimenez-Solomon, M. F.; Székely, G.; Livingston, A. G. Chem. Rev., 2014, 114, 10735-10806. https://doi.org/10.1021/cr500006j

10. Nagy, S.; Kozma, P.; Kisszékelyi, P.; Bezzegh D.; Huszthy P.; Kupai J. Studia UBB Chemia, 2017, 62, 183. https://doi.org/10.24193/subbchem.2017.1.16

11. Kupai, J.; Huszthy, P.; Szekely, K.; Toth, T.; Parkanyi, L. Arkivoc 2011, 77-93.

https://doi.org/10.3998/ark.5550190.0012.906 
12. Nagy, S.; Fehér, Z.; Kisszékelyi, P.; Huszthy, P.; Kupai, J. New J. Chem., 2018, 42, 8596. https://doi.org/10.1039/C8NJ01277F

13. Braje, W. M.; Frackenpohl, J.; Schrake, O.; Wartchow, R.; Beil, W.; Hoffmann, H. M. R. Helv. Chim. Acta, 2000, 83, 777-792. https://doi.org/10.1002/(SICI)1522-2675(20000412)83:4<777 ::AID-HLCA777>3.0.CO;2-W

14. McCooey, S. H.; Connon, S. J. Org. Lett., 2007, 9, 599-602. https://doi.org/10.1021/o10628006

15. Vakulya, B.; Varga, S.; Soós, T. J. Org. Chem., 2008, 73, 3475-3480. https://doi.org/10.1021/jo702692a

16. del Pozo, S.; Vera, S.; Oiarbide, M.; Palomo, C. J. Am. Chem. Soc., 2017, 139, 15308-15311. https://doi.org/10.1021/jacs.7b09124

17. Bae, H. Y.; Some, S.; Lee, J. H.; Kim, J. Y.; Song, M. J.; Lee, S.; Zhang, Y. J.; Song, C. E. Adv. Synth. Catal., 2011, 353, 3196-3202. https://doi.org/10.1002/adsc.201100458

18. Nagy, S.; Dargó, G.; Kisszékelyi, P.; Fehér, Z.; Simon, A.; Barabás, J.; Höltzl, T.; Mátravölgyi, B.; Kárpáti, L.; Drahos, L.; Huszthy, P.; Kupai, J. New J. Chem., 2019, 43, 5948. https://doi.org/10.1039/C8NJ06451B

19. Rombola, M.; Sumaria, C. S.; Montgomery, T. D.; Rawal, V. H. J. Am. Chem. Soc., 2017, 139, 5297-5300. https://doi.org/10.1021/jacs.7b01115

20. Rombola, M.; Rawal, V. H. Org. Lett., 2018, 20, 514-517. https://doi.org/10.1021/acs.orglett.7b03549

21. Yang, M.; Chen, C.; Yi, X.; Li, Y.; Wu, X.; Li, Q.; Ban, S. Org. Biomol. Chem., 2019, 17, 2883-2886. https://doi.org/10.1039/C9OB00330D
22. Chen, C.; Wei, R.; Yi, X.; Gao, L.; Zhang, M.; Liu, H.; Li, Q.; Song, H.; Ban, S. J. Org. Chem., 2019, 84, 15655-15661. https://doi.org/10.1021/acs.joc.9b02176

23. Rodríguez-Ferrer, P.; Naharro, D.; Maestro, A.; Andrés, J. M.; Pedrosa, R. Eur. J. Org. Chem., 2019, 38, 6539-6549. https://doi.org/10.1002/ejoc.201901327

24. Nagy, S.; Fehér, Z.; Dargó, G.; Barabás, J.; Garádi, Z.; Mátravölgyi, B.; Kisszékelyi, P.; Dargó, Gy.; Huszthy, P.; Höltzl, T.; Balogh, G. T.; Kupai, J. Materials, 2019, 12, 3034 https://doi.org/10.3390/ma12183034

25. Wu, W. B.; Wang, N.; Xu, J. M.; Wu, Q.; Lin, X. F. Chem. Commun., 2005, 18, 2348-2350. https://doi.org/10.1039/B501338K

26. Xu, J. M.; Liu, B. K.; Wu, W. B.; Qian, C.; Wu, Q.; Lin, X. F. J. Org. Chem., 2006, 71, 3991-3993. https://doi.org/10.1021/jo0600914

27. Lin, S. W.; Sun, Q.; Li, R. T.; Cheng, T. M.; Ge, Z. M. Synthesis, 2007, 13, 1933-1938. https://doi.org/10.1055/s-2007-983733

28. Bodor, N.; Kaminski, J. J.; Selk, S. J. Med. Chem., 1980, 23, 469-474. https://doi.org/10.1021/jm00179a001

29. Ozaki, S.; Watanabe, Y.; Hoshiko, T.; Mizuno, H.; Ishikawa, K.; Mori, H. Chem. Pharm. Bull., 1984, 32, 733-738. https://doi.org/10.1248/cpb.32.733

30. Nagy, S.; Fehér, Z.; Kárpáti, L.; Bagi, P.; Kisszékelyi, P.; Koczka, B.; Huszthy, P.; Pukánszky, B.; Kupai, J. Chem. Eur.J., 2020, 26,13513. https://doi.org/10.1002/chem.202001993

31. Pandey, S.; Srivastava, A. K. Ind. J. Chem. Technol., 1999, 6, 313-316. ISSN: 0975-0991 (Online); 0971-457X (Print) 


\section{Synthesis, application, and recycling of new asymmetric organocatalysts containing a cinchona skeleton}

During my work, I dealt with the preparation of double hydrogen-bond donor organocatalysts, and showed the importance, efficiency and applicability of the catalysts. These catalysts can be utilized in asymmetric reactions widely applied in the pharmaceutical industry (Michael, aza-Markovnikov, aza-Diels-Alder, and conjugate addition reactions). The asymmetric syntheses of these reaction products are crucial, as it is a more environmentally friendly and cost-effective method than resolution. However, regulations, which require that the active ingredients must not contain a heavy metal, may favor organocatalysts to transition metal catalysts. Another essential feature is the lower price, moreover the organocatalysts are usually not sensitive to conditions such as moisture, air, and they are applicable in a wide $\mathrm{pH}$ range. My goal was to prepare organocatalysts containing cinchona skeleton, which can asymmetrically catalyze the above-mentioned reactions and facilitate their activity.

At first, glucose-cinchona thiourea was prepared for this purpose, however, the resulting compound showed low enantioselectivity in the Michael addition reaction. The cinchona skeleton was shown to be necessary for the reactions, as no enantioselectivity was observed when the glucose derivative was connected to other bases.

After that, I wanted to investigate the effects of the most commonly used cinchona-based organocatalyst derivatives on their catalytic activity. Starting from quinine, I prepared several such derivatives, during which I changed the saturation of the substituent of the quinuclidine moiety and the effect of the substituent at the $\mathrm{C} 9$ position. I began an in-depth study of the 12 catalysts. Since hydrogen-bonding plays an important role in the behavior of these organocatalysts, their $\mathrm{p} K_{\mathrm{a}}$ values were measured in several solvents. Thus, we obtained a comprehensive view of both the acidity (of the group responsible for hydrogen-bonding), and the basic nature (of the nitrogen atom responsible for their basicity) of these catalysts. I have found that although researchers can produce „,new catalysts" with minor changes, their effect will not necessarily be different from the previous ones. Thus, if the only goal is to build in the cinchona skeleton, it is advisable to start with the most easily available material, in our case quinine, which, also, has the advantage of allowing other important transformations by the double bond on the quinuclidine unit, such as polymerization or modification with a functional group for immobilization.

Although cinchona thioureas and squaramides have already proved their effectiveness in several asymmetric reactions, there are some for which they are not sufficiently active. An example for such a reaction is aza-Diels-Alder reaction, in which neither thiourea nor squaramide unit containing organocatalysts gave product. To increase the acidity of the hydrogen-bond donor unit, just as urea was replaced by thiourea, we tried to produce thiosquaramides. Their preparation was not free of obstacles, as the thionation of the starting materials and intermediates of squaramides could not be carried out. Rawal et al. synthesized a sterically crowded squaric acid ester, and after its dithionation, thiosquaramides were prepared by the traditional substitution method as squaramides are obtained. The disadvantage of this method is that both the starting material and the intermediates are sensitive to acidic conditions and decompose on silica gel. To avoid this, we found an easier way to prepare the corresponding dithio compound by thionating the already prepared and purified squaramides, sparing ourselves from the cumbersome purification of intermediates.

Unfortunately, in the methods I have listed so far, the catalysts used have not been recycled. We also wanted to accomplish projects to recycle the catalysts (homogeneous and heterogeneous recycling) after they had been applied.

The homogeneous recycling of catalysts is still challenging today. As a method, I used the OSN technique, which has already been implemented on an industrial scale: molecules with different sizes can be separated by applying pressure with the help of a properly selected membrane. I tried to choose a reaction in which the resulted products' molecular sizes differ significantly from the sizes of the catalysts I used, so I chose the aza-Markovnikov reaction. First, I optimized the reaction conditions, reducing both the large excess of reagent and the amount of base used as a catalyst. Thus, I had a system, which is greener based on Sheldon's E factor. I replaced DMF by acetonitrile, a more environmentally friendly one. After this optimization, I used cinchona-based organocatalysts in aza-Markovnikov reaction. Among these catalysts, the most basic cinchona compound having an amino group at the C9 position showed the best yields, but unfortunately, enantioselectivity was not observed with these catalysts. However, the yields proved to be better than those gained with other non-recyclable bases. Measuring the retention of molecules using different membranes in OSN, we have found a system in which the retention of the catalysts was close to $100 \%$, allowing the catalysts to be recycled even in combination with their multiple applications.

I solved the heterogeneous recycling of cinchona squaramides by attaching them to PGMA. Although several polymer supports are available at an affordable price, my later goal was to use the catalysts in a continuous flow system loading them into a column; and prepare polymer support in a well-defined form and feasible way. The PGMA support was the right choice, because there are several solid supports, such as silica gel, which can catalyze the reaction, but decrease enantioselectivity, which is problematic. Not to mention that, in general, polymer supports have a wide particle size distribution, which may even be responsible for column clogging. PGMA is inert to the reaction, and its insolubility can be increased by subsequent cross-linking. Thanks to its reactive epoxy groups, it readily reacts with compounds containing a primary amino group. Modification was performed on three cinchona squaramides, to which I bonded a primary amino group at different positions using different linkers. The resulted precatalysts were reacted with the support to give heterogeneous catalysts, which I successfully used in asymmetric Michael addition. My future goal is to use the best catalyst in other test reactions, all in a continuous flow system, which is more favorable than centrifugation.

Based on my research, I can say that the development of organocatalysts is important and useful. They should be tested in several chemical reactions necessary for the pharmaceutical industry, as the need for the production of enantiomerically pure pharmaceutical ingredients increases. 